\title{
OPTIMALISASI PENGOLAHAN LIMBAH ORGANIK PASAR TRADISIONAL DENGAN PEMANFAATAN EFFECTIVE MICROORGANISME4 (EM4)
}

\author{
Nurul Fuadi \\ Jurusan Fisika UIN Alauddin Makassar \\ E-mail: nurul.fuadi@uin-alauddin.ac.id
}

\begin{abstract}
Abstrak: Penelitian ini dilakukan untuk mengetahui cara pengolahan limbah organik pasar tradisional dengan pemanfaatan bakteri aktivator Effective Microorganism4 (EM4) dan untuk mengetahui kandungan limbah organic melalui pengujian X-Ray Fluorescence (XRF). Penelitian ini dilaksanakan di desa Bontobaddo, kab. Gowa dan Laboratorium Fisika di Science Building, Universitas Hasanuddin. Proses pengambilan data dilakukan melalui metode pengukuran langsung di lapangan dan metode eksperimen, prosesnya dimulai dengan mempersiapkan alat dan bahan, melakukan pengumpulan bahan baku yakni sampah organik dan kotoran sapi, kemudian melakukan pengomposan dengan menambahkan aktivator EM4 selama 10 hari dengan metode Anaerob, kemudian melakukan uji XRF untuk mengetahui kandungan kompos. Hasil penelitian diperoleh $\mathrm{pH}$ sebelum fermentasi masing pada sampel A, sampel B dan sampel C adalah 5.5, 5.5 dan 5.0. $\mathrm{pH}$ setelah fermentasi berturut turut pada sampel A, sampel $\mathrm{B}$ dan sampel $\mathrm{C}$ adalah 5.0, 5.0 dan 4.0. Kemudian suhu yang diperoleh dari hasil fermentasi yaitu sampel A $31^{\circ} \mathrm{C}$, sampel B $29^{\circ} \mathrm{C}$ dan sampel C $28^{\circ} \mathrm{C}$. Uji kelembaban yang diperoleh menunjukkan kompos bersifat basah. Selanjutnya dilakukan uji kandungan kompos menggunakan X-Ray Fluorescence (XRF) diperoleh bahwa kompos hasil fermentasi anaerob dengan penambahan aktivator EM4 adalah Fe, K,Si, Ca dan P.
\end{abstract}

Kata Kunci: Limbah organik, Kotoran sapi, Effective Microorganism4 (EM4), XRF.

\section{PENDAHULUAN}

ampah menjadi permasalahan serius di berbagai kota besar di Indonesia tak terkecuali di kota Makassar. Peningkatan jumlah penduduk berbanding lurus dengan sampah yang dihasilkan tiap harinya. Tidak sedikit permasalahan sosial yang muncul di masyarakat. Tiap hari masyarakat menghasilkan sampah, baik itu sampah dari masing-masing rumah, jalan, pasar ataupun rumah makan, baik berupa sampah organik, maupun non organik. Sampah pasar yang tidak mengalami pengelolaan secara baik akan menimbulkan pencemaran lingkungan. Sampah-sampah tersebut masih mengandung kadar air yang tinggi serta mengandung bahan-bahan organik berupa karbohidrat, protein, dan lemak yaitu salah satunya adalah limbah sayuran. Sampah organik pada umumnya mengalami pembusukan seperti daun, sisa 
makanan dan sampah organik lainnya. Sedangkan sampah anorganik pada umumnya tidak mengalami pembusukan seperti plastik, logam dan lainnya (Unus, 2002).

Limbah merupakan sampah sisa produksi yang mengandung bahan-bahan yang dapat menimbulkan polusi dan dapat menganggu kesehatan. Pada umumnya sebagian orang mengatakan bahwa sampah adalah bahan yang tidak berguna dan tidak dapat dimanfaatkan kembali yang harus segera dibuang. Jika pembuangan dilakukan secara terus menerus maka akan menimbulkan penumpukan sampah

Saat ini telah dilakukan beberapa penelitian pembuatan kompos dengan menggunakan bantuan aktivator Effective Microorganism4 (EM4). Aktivator EM4 merupakan bahan yang mengandung beberapa mikroorganisme yang sangat bermanfaat dalam proses pengomposan. Manfaat EM4 sendiri dapat meningkatkan fermentasi limbah dan sampah organik, meningkatkan ketersediaan unsur hara untuk tanaman, serta menekan aktivitas serangga, hama dan mikroorganisme pathogen (Indriani, 2007). Berdasarkan latar belakang di atas, maka dilakukan penelitian yang bertujuan untuk mengetahui cara pengolahan limbah organik pada pasar tradisional dengan pemanfaatan bakteri aktivator Effective Microorganism4 (EM4) dan untuk mengetahui kandungan limbah organik melalui pengujian $X$-Ray Flouroscence (XRF)

\section{METODE PENELITIAN}

Proses pengambilan data pada penelitian ini dilakukan melalui metode pengukuran langsung di lapangan di desa Bontobaddo, Kab, Gowa dan metode eksperimen di Laboratorium Fisika di Science Building, Universitas Hasanuddin.

\section{Proses pembuatan pupuk kompos}

Menyiapkan bahan baku yang berasal dari limbah organik pasar dengan berbagai jenis sayuran; Limbah yang masih berukuran besar dirajang kecil kecil agar pembusukannya terjadi secara sempurna; Menimbang larutan EM4 yang sudah ditambahkan dengan larutan gula sebanyak masing-masing $3 \mathrm{~kg}$.

Tabel 1. Variasi sampel penelitian

\begin{tabular}{ll}
\hline \multicolumn{1}{c}{ Massa $(\mathrm{kg})$} & \multicolumn{1}{c}{ Sampel } \\
\hline $2: 1: 0,1$ & Limbah sampah organik : Kotoran Sapi : EM4 \\
\hline $2: 1: 0,2$ & Limbah sampah organik : Kotoran Sapi : EM4 \\
\hline $2: 1: 0,3$ & Limbah sampah organik : Kotoran Sapi : EM4 \\
\hline
\end{tabular}

Menimbang bahan yang dibutuhkan sesuai dengan perbandingan massa (lihat tabel 1) dengan total massa $30 \mathrm{~kg}$ untuk tiap bak; Kemudian menambahkan kotoran sapi dan cairan bioaktivator Effective Microorganisme (EM4) dengan perbandingan massa seperti pada tabel 1; Mengaduk rata semua bahan yang digunakan dan menutup wadah dengan rapat; Mendiamkan pupuk kompos selama 10 hari dan mengamati perubahan pupuk kompos; Mengukur perubahan suhu, $\mathrm{pH}$ dan kelembaban pupuk kompos tiap sampel.

\section{Pengujian kandungan kompos menggunakan X-Ray Flouroscence (XRF)}

Sampel kompos yang telah jadi dikeringkan dibawah terik matahari selama 3 hari masing-masing selama 6 jam; Sampel (kompos) yang telah dikeringkan diletakkan pada 
wadah yang telah ditimbang sebesar 2 gram; Memasukkan sampel kedalam XRF (XRay Flouroscence); Kemudian melakukan uji sampel.

\section{HASIL DAN PEMBAHASAN}

\section{Pengukuran pH}

$\mathrm{pH}$ merupakan parameter penting dalam menentukan layak atau tidaknya hasil dari pengomposan. Pengukuran $\mathrm{pH}$ dilakukan untuk mengetahui berapa $\mathrm{pH}$ awal sebelum dan setelah terjadi perombakan secara anaerob oleh bakteri. Penelitian ini dilakukan sebanyak dua kali pengukuran $\mathrm{pH}$ yakni pengukuran $\mathrm{pH}$ sebelum fermentasi dan setelah fermentasi selama 10 hari. Pengukuran $\mathrm{pH}$ dilakukan dengan menggunakan $\mathrm{pH}$ meter. Data hasil pengukuran nilai $\mathrm{pH}$ pada kompos sebagai berikut :

Tabel 2. Data pengukuran $\mathrm{pH}$ sebelum Fermentasi

\begin{tabular}{|c|c|c|}
\hline Sampel & Konsentrasi EM4 (kg/Mr) & $\mathrm{pH}$ \\
\hline Sampel 1 & 0,1 & 5,5 \\
\hline Sampel 2 & 0,2 & 5,5 \\
\hline Sampel 3 & 0,3 & 5,0 \\
\hline
\end{tabular}

Table 3. Data pengukuran $\mathrm{pH}$ setelah fermentasi 10 hari

\begin{tabular}{|c|c|c|}
\hline Sampel & Konsentrasi EM4 (kg/Mr) & $\mathrm{pH}$ \\
\hline Sampel 1 & 0,1 & 5 \\
\hline Sampel 2 & 0,2 & 5 \\
\hline Sampel 3 & 0,3 & 4 \\
\hline
\end{tabular}

Dari hasil penelitian tabel 2 dan tabel 3 menujukkan hasil pengukuran $\mathrm{pH}$ pada sampel cenderung berada pada rentang 4-6. Tabel 2 menunjukkan adanya kecenderungan $\mathrm{pH}$ yang bersifat asam sebelum difermentasikan. Dan setelah proses fermentasi selama 10 hari $\mathrm{pH}$ masih berada pada kisaran nilai asam (tabel 3). $\mathrm{pH}$ yang optimum untuk proses pengomposan berkisar antara 6,5-7,5. Pada $\mathrm{pH}$ kotoran ternak umumnya berkisar antara 6,8 - 7,4. Proses pengomposan sendiri akan menyebabkan perubahan pada bahan organik dan $\mathrm{pH}$ bahan itu sendiri. $\mathrm{pH}$ kompos yang sudah matang biasanya mendekati netral (anonim 2014).

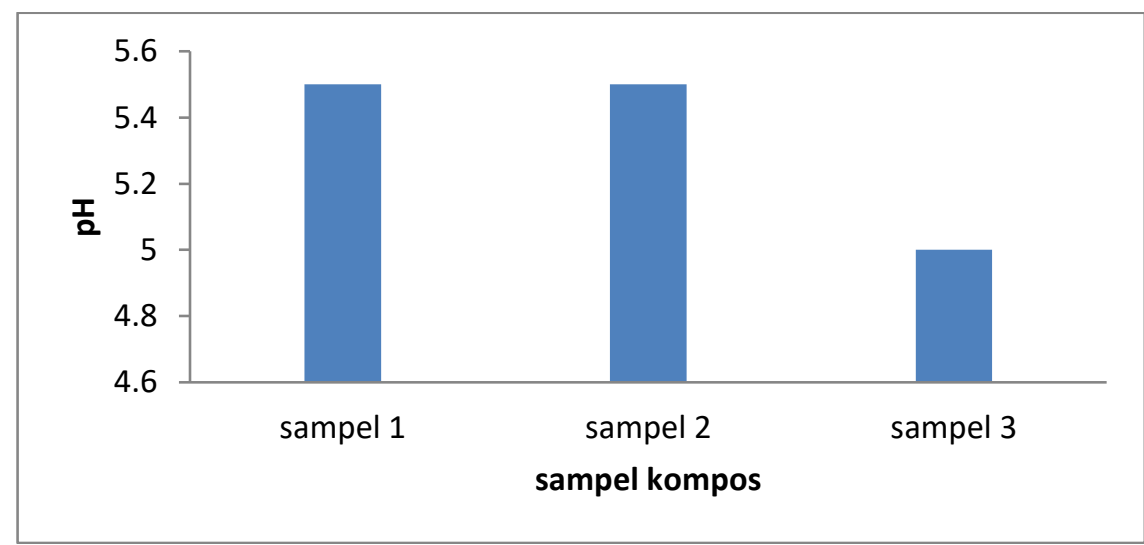

Gambar 1. Grafik pH sebelum fermentasi 
Pada tabel 3 diperoleh nilai $\mathrm{pH}$ setelah proses fermentasi antara 4-5. $\mathrm{pH}$ pada sampel A dan B bernilai 5 sedangkan sampel $\mathrm{C}$ memiliki nilai $\mathrm{pH}$ 4. Pada sampel A dan $\mathrm{B}$ mendekati $\mathrm{pH}$ netral dan termasuk belum menunjukkan nilai optimum dalam proses pengomposan. Nilai $\mathrm{pH}$ yang berada pada kisaran netral akan mudah diserap dan digunakan tanaman, serta berguna untuk mengurangi keasaman tanah karena sifat asli tanah adalah bersifat asam. Nilai $\mathrm{pH}$ yang cenderung mendekati nilai asam akan membuat bakteri tidak dapat tumbuh secara maksimal karena lingkungan yang basah akan cenderung bersifat racun bagi mkikroorganisme.

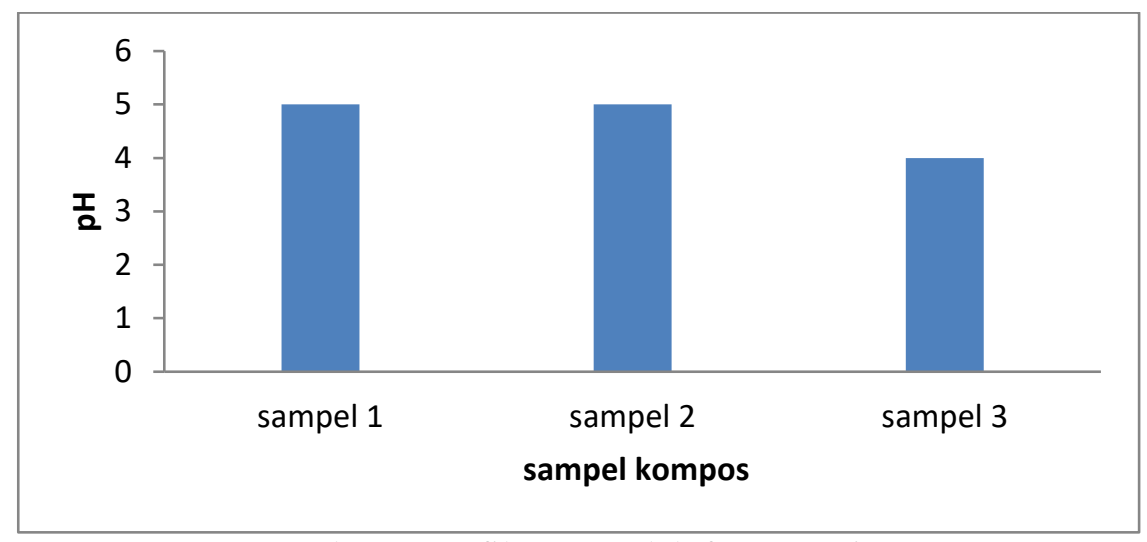

Gambar 2 grafik pH setelah fermentasi

\section{Pengukuran suhu dan kelembaban}

Suhu merupakan salah satu faktor yang mempengaruhi laju pengomposan, karena mikroorganisme perombak masing-masing memiliki suhu optimum dalam aktivitasnya. Suhu pengomposan yang baik adalah $10^{\circ} \mathrm{C}-45^{\circ} \mathrm{C}$. Semakin tinggi suhu akan semakin banyak konsumsi oksigen dan akan semakin cepat pula proses dekomposisi. Djuarnani, dkk, 2005, menyatakan bahwa mikroorganisme yang hidup pada suhu rendah $\left(10^{\circ} \mathrm{C}-45^{\circ} \mathrm{C}\right)$ adalah mikroorganisme mesofilik dan mikroorganisme yang hidup hidup pada suhu tinggi $\left(45^{\circ} \mathrm{C}-65^{\circ} \mathrm{C}\right.$ adalah mikroorganisme termofilik.

Pada penelitian ini dilakukan pengukuran suhu dalam ember, nilai suhu lingkungan serta pengukuran kelembaban. Pengukuran dilakukan menggunakan Soil Survey Instrument yang mengukur kelembaban sekaligus mengukur suhu kompos. Penelitian ini dilakukan dengan proses anaerob karena sampel dimasukkan kedalam ember yang ditutup rapat. Nilai suhu masing-masing ember sampel dicatat sebelum dan sesudah pengomposan (sebelum dan sesudah proses fermentasi). Begitupula dengan suhu lingkungan yang diukur menggunakan termometer raksa.

Pengukuran dilakukan pada pukul 17.00 WITA. Berikut adalah data hasil pengukuran setelah 10 hari fermentasi.

Tabel 4. Pengukuran Nilai Suhu dan Kelembaban

\begin{tabular}{lccc}
\hline \multirow{2}{*}{ Sampel } & \multicolumn{2}{c}{ Suhu $\left({ }^{\circ} \mathrm{C}\right)$} & Kelembaban \\
\cline { 2 - 3 } & Kompos & Lingkungan & \\
\hline Sampel 1 & 31 & 29 & Basah \\
\hline Sampel 2 & 29 & 29 & Basah \\
\hline Sampel 3 & 28 & 29 & Basah \\
\hline
\end{tabular}

Dari hasil penelitian menunjukkan nilai suhu yang sudah termasuk dalam suhu optimal dalam proses pembuatan pupuk kompos. Jika kita melihat tabel 4, bahwa suhu 
kompos masih berada dalam kisaran suhu optimal dengan nilai antara $10^{\circ} \mathrm{C}-45^{\circ} \mathrm{C}$.

Menurut data yang ditunjukkan tabel 4 diperoleh nilai kelembaban yang seragam pada tiap sampel yang memiliki kelembaban rata-rata basah. Hal ini diperoleh karena tingginya nilai kadar air yang terkandung dalam bahan yang digunakan. Limbah organik juga merupakan limbah sayur dan buah yang mengandung kadar air yang tinggi pula. Untuk kelembaban optimal pada proses pembentukan kompos adalah 40\%-60\%. Apabila kurang dari 40\% maka pengomposan akan berlangsung lambat, sebaliknya jika lebih dari $60 \%$ maka menyebabkan unsur hara tercuci dan volume udara dalam kompos berkurang. Akibatnya aktivitas mikroorganisme akan menurun dan memunculkan bau tak sedap ( Kusumawati, 2011)

\section{Pengujian X-Ray Flouroscence (XRF)}

Uji kualitas fisis (kandungan) pupuk kompos yang diperoleh menggunakan XRay Flouroscence (XRF). Tujuan pengujian kualitas fisis (kandungan) pada pupuk kompos agar dapat mengetahui unsur hara apa saja yang terdapat pada pupuk kompos yang dihasilkan. Unsur yang terbaca pada spektrum dapat diliat pada tabel berikut:

Tabel 5. Hasil Pengujian Kandungan pada Pupuk Kompos Menggunakan XRF pada 3 sampel kompos

\begin{tabular}{|c|c|c|c|c|c|c|}
\hline \multirow{2}{*}{ Elemen } & \multicolumn{3}{|c|}{ A } & \multicolumn{2}{c|}{ B } & \multicolumn{2}{c|}{ C } \\
\cline { 2 - 7 } & $\begin{array}{c}\text { kandungan } \\
(\%)\end{array}$ & $\begin{array}{c}\text { Standar } \\
\text { Error (\%) }\end{array}$ & $\begin{array}{c}\text { kandungan } \\
(\%)\end{array}$ & $\begin{array}{c}\text { Standar } \\
\text { Error (\%) }\end{array}$ & $\begin{array}{c}\text { kandungan } \\
(\%)\end{array}$ & $\begin{array}{c}\text { Standar } \\
\text { Error (\%) }\end{array}$ \\
\hline $\mathrm{Fe}$ & 28.91 & 4.95 & 37.27 & 0.38 & 33.10 & 0.47 \\
\hline $\mathrm{K}$ & 18.00 & 3.09 & 18.82 & 0.22 & 14.94 & 0.25 \\
\hline $\mathrm{Si}$ & 6.33 & 1.41 & 15.55 & 0.76 & 27.95 & 0.92 \\
\hline $\mathrm{Ca}$ & 10.69 & 1.83 & 14.84 & 0.38 & 11.01 & 0.30 \\
\hline $\mathrm{Px}$ & 2.06 & 0.48 & 3.21 & 0.27 & 3.97 & 0.37 \\
\hline
\end{tabular}

Berdasarkan tabel 5 menyatakan besar energi yang digunakan dapat menunjukkan unsur yang terdapat dalam pupuk kompos yaitu Ferrum (Fe), Kalium (K), Silika (Si), Calsium (Ca), Px (Fospor) yang diperoleh dari pengujian XRF.kandungan unsur hara juga dipenagruhi oleh kadar asam bahan kompos. Nilai $\mathrm{pH}$ kompos berpengaruh terhadap kelarutan unsur mikro seperti $\mathrm{Fe}, \mathrm{Zn}, \mathrm{Cu}, \mathrm{B}, \mathrm{M}$ dan $\mathrm{Mo}$. (Novizan, 2005)

Menurut penelitian Surtinah (2013), yang menyatakan bahwa $\mathrm{Fe}$ yang merupakan inti dari sitokrom yang berperan dalam proses asimilasi tanaman dalam menghasilkan energi yang digunakan pada proses biokimia tanaman. Berdasarkan hasil analisis XRF hasil uji kualitas (kandungan) pada pupuk kompos didapatkan unsur yang dominan pada unsur Ferrum $(\mathrm{Fe})$. Nilai Fe tertinggi sebesar $37.27 \%$ terdapat pada kandungan sampel B lalu pada sampel C sebesar 33.10\% dan sampel A sebesar $28.91 \%$.

Standarisasi pada kandungan unsur $\mathrm{K}$ harus berada diatas jumlah minimal yang telah ditetapkan. Dari hasil penelitian ini pada sampel B sebesar $18.82 \%$ yang paling banyak mengandung unsur $\mathrm{K}$ paling banyak, lalu sampel A $18.00 \%$ dan sampel C sebesar $14.94 \%$. menurut penelitian (Zukni, Ahmad, 2013) menyatakan bahwa kompos ini dapat digunakan pada tanaman kentang, karena dengan unsur $\mathrm{K}$ yang cukup dapat mencegah pengkerutan dan penggulungan pada daun kentang, dapat juga untuk 
mempertahankan agar daun tetap hijau tua tidak mengalami penguningan dan bintikbintik kecoklatan pada daunnya, dan dapat juga di gunakan pada tanaman jeruk untuk mencegah buah berjatuhan sebelum masak, dengan terpenuhinya kebutuhan unsur $\mathrm{K}$. Kalium (K) digunakan oleh mikroorganisme dalam bahan substrat sebagai katalisator, kehadiran bakteri dengan segala aktivitasnya sangat berpengaruh terhadap peningkatan kandungan kalium.. Kalium merupakan katalisator bagi mikroorganisme untuk mempercepat fermentasi.

Unsur $\mathrm{Ca}$ juga berperan penting dalam pertumbuhan luas daun, merangsang pertumbuhan akar dan perkembangan daun pada tanaman, dari hasil yang diperoleh bahwa jumlah kandungan unsur Ca sebesar $14.84 \%$ pada sampel B. Seperti yang dikutip dalam penelitian (Surtinah, 2013) yang menyatakan bahwa berperan kandungan unsur Ca dalam menetralkan asam-asam organik yang dihasilkan pada proses metabolisme tanaman, sehingga tanaman terhindar dari keracunan, dan unsur $\mathrm{Ca}$ dapat menaikkan $\mathrm{pH}$, bila unsur ini berada dalam tubuh tanaman, dengan kenaikan $\mathrm{pH}$ dapat mengaktifkan enzim phofoenolpiruvat karboksilase. Kandungan unsur $\mathrm{Ca}$ juga dapat mengaktifkan pembentukan bulu-bulu akar dan biji serta menguatkan batang. Membantu keberhasilan penyerbukan. Membantu pemecahan sel. membanti aktivitas beberapa enzim pertumbuhan. Serta menetralisir senyawa dan kondisi tanah yang merugikan.

Untuk kandungan unsur Si yang diperoleh menunjukkan hasil yang tergolong tinggi, dimana nilai optimal pada kosentrasi Si yang dibutuhkan pada tanaman jenis jerami berkisar pada 8-10\%. Bahkan, menurut (Makarim, A.K.,2007), pada tanaman padi dapat memberikan hasil yang baik apabila jerami padi yang mengandung $\mathrm{Si}<$ $11 \%$. Dari hasil yang diperoleh menunjukkan adanya nilai Si yang tinggi terdapat pada sampel C yaitu $27.95 \%$, dan berturut-turut adalah sampel B, dan A adalah $15.55 \%$ dan $6.33 \%$.

Unsur Fosfor $(\mathrm{P})$ dapat juga mempengaruhi pertumbuhan tanaman dan sangat penting saat melakukan proses pemupukan dan dari hasil yang diperoleh bahwa sampel $\mathrm{C}$ yang memiliki kandungan $\mathrm{P}$ lebih banyak dari sampel lainnya yaitu sebesar 3,97\%. Menurut penelitian (Zukni, Ahmad. 2013) menyatakan bahwa Fosfor merupakan unsur untuk pertumbuhan di dalam tanaman, berfungsi untuk pembentukkan protein, lemak, biji-bijian. Fosfor di jumpai dalam tanah dan tanaman dalam bentuk organik dan anorganik yang berperan dalam proses pelepasan dan penyimpanan energi dalam metabolisme seluler. Dan menurut penelitian lainnya menyatakan kandungan unsur Fosfor $(\mathrm{P})$ termasuk unsur hara makro esensial yang sangat penting untuk pertumbuhan tanaman, tetapi kandungannya didalam tanah lebih rendah dibandingkan Nitrogen $(\mathrm{N})$, Kalium (K), dan Kalsium (Ca). Fosfor sebagian besar dari pelapukan batuan mineral alami, sisanya berasal dari pelapukan bahan organik. Sebagian besar fosfor yang mudah larut diambil oleh mikroorganisme tanah untuk pertumbuhan, fosfor ini akhirnya diubah menjadi humus.

Berdasarkan hasil uji kandungan yang diperoleh, didapatkan bahwa pupuk ini merupakan jenis pupuk yang dihasilkan dari rekayasa kimia, fisik atau biologis dan limbah organik yang digunakan merupakan hasil limbah pasar. Adanya kandungan Fe yang didapatkan berasal dari kandungan sawi yang digunakan pada penelitian ini sebagai bahan baku dan kemungkinan berasal dari air sumur yang digunakan pada larutan gula yang dicampur dengan EM4. 


\section{KESIMPULAN}

Berdasarkan hasil penelitianyang telah dilakukan, maka dapat disimpulkan bahwa pembuatan kompos dari bahan limbah organik pasar tradisional Panaikang, kota Makassar, Sulawesi Selatan dilakukan dengan cara mencampurkan limbah organik basah atau limbah sayur, kotoran sapi dan aktivator EM4, dengan variasi 3 sampel yang berbeda, kemudian didiamkan selama 10 hari secara anaerob; Berdasarkan hasil analisis XRF hasil uji kualitas fisis (kandungan) pada pupuk kompos didapatkan unsur Ferrum (Fe), Kalium (K), Silika (Si), Calsium (Ca), P (Fospor).

\section{DAFTAR PUSTAKA}

Anonim. 2014. Kompos. https://id.wikipedia.org/wiki/kompos (diakses pada agustus 2019)

Djuarnani, N., Kristiawan dan Setiawan, B.S. 2005. Cara Cepat Membuat Kompos. AgroMedia Pustaka : Jakarta.

Indriani, Y.H. 2007. Membuat Pupuk Organik Secara Singkat, Penebar Swadaya : Jakarta

Isroi. 2008. Kompos. Balai Penelitian Bioteknologi Perkebunan Indonesia : Bogor.

Isroi dan Yuliarti, N. 2009. Kompos Cara Mudah, Murah dan Cepat Menghasilkan Kompos. Andi : Yogyakarta.

Kusumawati N. 2011. Evaluasi Perubahan Temperatur, pH dan Kelembaban Media pada Pembuatan Vermikompos dari XCampuran Jerami Padi dan Kotoran sapi Menggunakan Lumbricus Rebellus. J.Inotek. 15 (1) : 45-46

Masrukan dan Rosika. 2008. Perbandingan hasil Analisis Bahan Bakar U-Zr dengan Menggunakan Teknik XRF dan SSA, Urania 14(1): 19, http://www.batan.go.id/03_Kajian_Masrukan.pdf, 21 Januari 2019.

Makarim, A.K. E. Suhartatik dan A. Kartohardjono. 2007. Silikon: Hara Penting pada Sistem Produksi Padi. Jurnal Iptek Tanaman Pangan Vol. 2 No. 2 - 2007.

Novizan. 2005. Petunjuk Pemupukan yang Efektif. Agromedia Pustaka : Jakarta.

Surtinah. 2013. Pengujian Kandungan Unsur Hara Dalam Kompos yang Berasal dari Serasah Tanaman Jagung Manis (Zea mays saccharata). Jurnal Ilmiah Pertanian Vol. 11, No. 1. 2013.

Unus, Suriawiria. 2002. Pupuk Organik Kompos dari Sampah. Bioteknologi Agroindustri. Humaniora Utama Press Bandung.

Zukni, Ahmad. 2013. Analisis Kandungan Unsur npk dalam Kompos Organik Limbah Jamur dengan Aktivator Ampas Tahu. Jurnal Pemerhati Pendidikan Biologi 